\title{
Phenophyology Studiesin Efforts Produced Off Season Citrus (Citrus nobilis var, microcarpa)
}

\author{
Sulistiawati N. P. A , Rai I. N*, Santosa IGN*, Astarini I. A* \\ \# Faculty of Agriculture, Warmadewa University \\ E-mail:anomsulis@yahoo.co.id
}

* Biology Department, Faculty of Mathematics and Natural Sciences, Udayana University

\begin{abstract}
Catur Village, Kintamani District, is the main siam citrus producer region in Bali, Indonesia. However, fruit production seasonal and fluctuate within a year. High production season, or on season is around June - August, while off season period is in December - January. Fluctuation in production makes it difficult to reach modern market that required for continuous supply. There is also a big demand for this fruit for local markets, in particular during festive celebration. It is therefore an urgent need to provide continuous supply of the fruit. Physiological manipulation of flowering in citrus is necessary, so that the balance of supply and demand of citrus fruit in the longer time span can be obtained. Theaim of this research was to study the physiology of flowering in citrus in an effort to obtain citrus fruit out of season. Targetedresult is to find out developmental phase and morphological changes of flower initiation to fruit formation, and able to formulate technology that can be applied in the effort to obtain flower and produce fruit of siam citrus off season, at Catur Village, Kintamani District. Bangli Regency, starting in February until November 2014
\end{abstract}

Keywords - off-season, on-season, flowering, citruss.

\section{INTRODUCTION}

Siam oranges (Citrus nobilis, micocarva var) is a tropical fruit commodities are very certain strategic to be developed. Judging from the level of consumption and the value of its trade. Citrus fruit is the most favored by the people with the level of consumption of about $5.1 \mathrm{~kg} /$ capita / year. Present importer, Indonesia is the second country after Malaysia's ASEAN. This is because the price is still slightly cheaper and less continuous production in citrus plants and the tint are less attractive [27]. The formation of fruit on fruit trees, flowering is determined by [13], therefore, the success of manipulation to get fruit out of season lies in the success of the induction process of arranging flowers. Flowering is a complex incident, in which morphological changes occur in the vegetative phase to the generative phase. Marked the beginning of the flowering time of the transition from the relatively simple structure of the leaves become more complex flower structure. The incident marked the beginning of the prospective cessation of meristem forming organs begin to produce leaves and flowers [15]. The ability of plants to reproductive phase transition depends on its ability to induce flower [14]. Setting flowering to produce citrus fruit out off- season very likely could be done, because the citrus crop naturally very short fruiting season only one time in a year that is the month from April to July. In fertilization on fruit trees very critical point to note is at flowering, so success in manipulation the formation of fruit out of season lies in the success of the induction process of arranging flowers. Citrus naturally seasonal flowering and fruiting (alternate bearing) is abundant flowering and fruiting in a season (on-season) as well as flowering and fruiting slightly the following season (off-season), and therefore contributes to the sustainability of production. Alternate bearing is influenced by environmental factors, especially the micro-climate, and plant endogenous factors [6]. Environmental factors are the most influential factor is the air temperature, air humidity, rainfall and light intensity [22]. The morphology of flowering is the occurrence of a change from the vegetative phase to the formation of floral organs, which is an event that flowering plants complexs. Success transition from the vegetative phase to phase reproduction depends on the ability of plants to induce flower [17]. Induction of flowering is a process which occurs outside stimuli toward the growing point and result induce primordial flowers [14].

To be the occurrence of flowering according to Lyndon (1990), the leaves must be able to produce substances needed by the driver of the flowering apex or stopper production inhibitor. So is the ability to receive a response apex and receive flowering stimulus is sufficient and stop 
receiving inhibitors of any part of the plant and then proceed to the formation of floral organs in the correct order. Therefore juvenile long period not only depends on the inability of the leaves produce flowering stimulus, but also depends on the apex inability to accept the stimulus. Flowering and fruiting in citrus plants is influenced by several factors including: the factors plant itself (genetic), environmental factors, hormones, and nutrient supply. Environmental factors are very influential rainfall, temperature, and light. The emergence of natural interest in events induction of flowering in citrus crops in Indonesia occurred in the dry season due to water stress and the rise of interest in the beginning of the rainy season [27].

Flowering citrus plants when it is still necessary assessment of flowering fenofisiology study, therefore, study the factors that affect interest allegedly induced or not induced flower very relevant done so that causal factors can be explained.

Flowering is initiated when the underarm / axillary bud dormancy in / induced for flowering shoots is often not the case in the whole armpit / shoots that exist in citrus. In the flowering season, often armpit / fruiting shoots were already abundant fruiting season (on-season) cannot be flowering in the next season (off-season). The important problems faced by citrus growers, so it has not the fluctuation continuity of production and the high inter-season crop production. In the harvest season or period on-season fruit production lot, otherwise the period of off-season fruit is very limited, even though almost no harvest fruit prices expensive. These circumstances led to the low income of farmers so that less passionate cultivate intensive plants. Based on the phenomenon that occurs in the armpit / shoots the citrus crop, the problems faced by the occurrence of a period of onseason and off-season periods that need further assessment as it pertains to how the condition can affect flowering and the buds cannot flowering ? How do I get armpit / tops are not flowering in the period off-season flowering so it can bear fruit out off-season. Based on the above problems, the objectives of this study were: to study the physiology of flowering in citrus plants based on: a. The phases of the formation or development of visually flowering. $b$. Exogenous factors, especially rainfall affecting the formation process flowering. The citrus. Based on the results of the study will be concluded flowering developmental phases as well as the formulation of environmental factors can cause flowering shoots that well in the off-season period. Outcomes of this research are: (1) Can study fenofisiology flowering morphology visually on citrus plants Found. (2) package of technology to be able to bloom in an effort to bear fruit out of season.

\section{LITERATURE}

Citrus (Citrus nobilis, var microcarpa) is a subtropical plant that can grow and production optimally at temperatures 25-30, optimum rainfall for growth and production is 1400 to $2400 \mathrm{~mm}$ / year with an average of 2-4 months of wet and 3 - 5 months to dry. Suitable planting in areas with an altitude of 700 - $1300 \mathrm{~m}$ above sea level (asl). For lowland citrus plants can grow at an altitude of 100-400 m above sea level (asl) requires a relatively dry climate with long dry period of about 3 months for the process of flowering.
Interest is a branch with leaves in a changed form, which limited growth, short segmented, and the leaves have changed shape. The parts of the flowers according Kowalska (2008) calyx (calyx) is green, canopy (crown flower / corolla), stamens / statements, pistil / pistil, flower stalks / pedicle, and reseptaculum [18].

The morphology of flowering is an event where there is a change to the formation of the vegetative organs of the flower, where the plant success phase transition from vegetative to reproductive phase depends on the ability of plants to induce flower [17]. Induction of flowering is a process in which the stimuli from the outside toward the growing point and the results induce primordial flowers [14].

To relax and be the flowering according to Lyndon (1990), the leaves must be able to produce a flowering booster substance be required by apex / stopper production inhibitor. So is the ability to receive a response and which apex receive sufficient stimulus flowering and stop receiving inhibitors of any part of plants and then proceed to the formation of floral organs in the correct order. In plant fruits flower and fruit formation success is determined by the induction phase is also called the phase transition from the vegetative phase to the reproductive phase in addition to environmental factors are also very closely related to the activity of the endogenous content of crops such as sugar, carbohydrates. Citrus naturally seasonal flowering and fruiting (alternate bearing), ie flowering and fruiting much on a season (on-season) and a little fruit in the next season (off-season), and therefore contributes to the sustainability of production.

According to Bernier et al, (1985) Flowering and fruiting on fruit crops is influenced by environmental factors, especially microclimate and crop endogenous factors, such as carbohydrates and growth hormone. Environmental factors affecting growth in plant physiological activity that affects the phases of plant growth and development. Elements that can affect the climate unnsur physiological processes such as air temperature, air humidity, rainfall, rainy days, and light. According Pidkowich et al, (1999) and Rai et al, (2010) the formation of fruit set failure caused by environmental factors grew less supportive or less optimal because the physiological processes of plants because it seeks to insufficient nutrients, water, and carbohydrate content [23],[31] . Poerwanto research results (2003) show that, with the application paklobutrazol, prohezadion-ca and strangulation significant effect on the emergence of flower buds, flowers and citrus fruits are formed [27].

Fenofisiology is the study of the cycle of shoot growth, flowering, $n$ easy way to comply with the conference paper formatting requirements is to use this document as a template and simply type your text into it. fertilization and physiological changes that occur. Understanding fenofisiology fruit trees are concerned for guiance farm management, so that the provision of the means of production and manipulation of plants can be done at the right time and crop production can be predicted with accuracy better and perfect. Citrus fruit and other tropical fruits not much is known about fenofisiology studies. Though understanding of fenofisiology very important in determining the production of fruit. Research on temperate fruit trees are very advanced, so that entrepreneurs oranges, 
apples, grapes, peaches, and other temperate fruits already know with certainty fenofisiology fruit trees. Thus, there is certainty in managing the garden and in the production of fruit. Fenofisiology study is a specific approach that is useful for the development of strategies to improve the appearance of the fruit trees, minimize competition between vegetative and generative growth or fruit formation. The final goal is to limit excessive vegetative vigor to encourage toward the formation of larger fruits, maintain a balance between vegetative and generative phases [14] and cope with large fluctuations between crop harvest or overcome biannual bearing [27].

\section{RESEARCH METHODOLOGY}

Before the first exploratory study was conducted to determine the location to be selected as a research site. After the specified location citrus production center in the village of Chess lies $12 \mathrm{~km}$ northwest of the city district of Kintamani, which is located between the middle-tenganh Writing Mountains, Batur, Chess, and the Mangu Mountains either side of the three districts in the regency of Bangli Badung, Buleleng and Bangli Regency. Chess village location situated at an altitude of 1450 meters above sea level (asl) with an area of 746 hectares of land which is divided into 630 moor, $25 \mathrm{Ha}$, ha plantation of 320 people and an area of 60 hectares of forest. Commencement of research activities that began in February until November 2014.

\section{RESULTS AND DISCUSSION}

\section{A. Observations Vegetative to Reproductive Development Phase}

Citrus plant is a plant that is in his life is divided into two periods, namely when the plants are still in the vegetative phase (juvenile), where the immature fruit and mature plants (reproductive) / period plants produce fruit. Transition to generative growth of vegetative growth in citrus plants are very specific, which will stop the growth and development of the (dormant). Plant citrus trees with a height 2-5 meters, with irregular canopy and shade, many branches, and small branches.

Citrus plant leaves are generally dark green, pinnate leaves with bone intermittent and leaves jagged edges, with a length of $6-8 \mathrm{~cm}$, width is approximately $4 \mathrm{~cm}$ and petiole 1 - 1,5 cm. This includes: (2004) says that the citrus flower initiation when the axillary buds begin to occur leaf color changes or the emergence of young leaf buds. Furthermore Rismunanadar (2009) said after the young leaf buds grow, a few days later appeared on the flower buds of citrus plants.

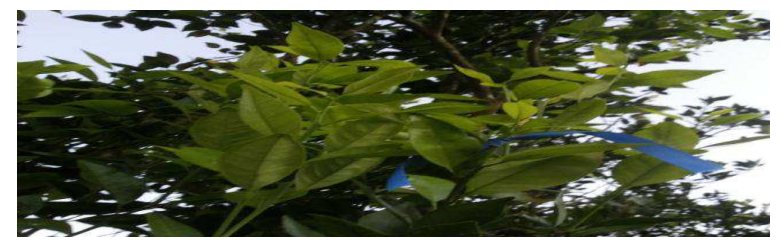

Fig. 1. Formation of the young leaves as a sign of change in vegetative phase to the reproductivphase.
Start bud formation flower buds distance when first appeared approximately 3 to 4 weeks from the time the emergence of the young leaves are light green transparent. Interest is a branch with leaves in a changed form, which limited growth, short segmented, and its leaf shape has changed. The parts of the flowers according Kowalska (2008) calyx (calyx) is green, canopy (crown flower / corolla), stamens / statements, pistil / pistil, flower stalks / pedicle, and receptaculum. Flowering is a critical point on the fruit trees, in determining the formation of the fruit [13], which according to Ogaya and Paneulas (2007), the process of flower formation is strongly influenced by exogenous factors (environmental) and endogenous plant [22].

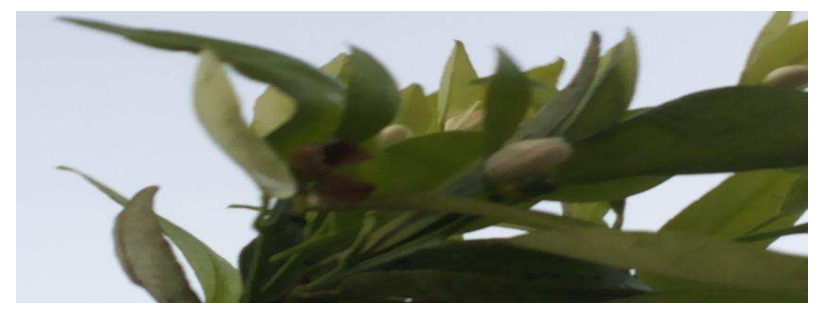

Fig. 2 The Formation of flower bud on citrus

Release of bud swelling stage of bud

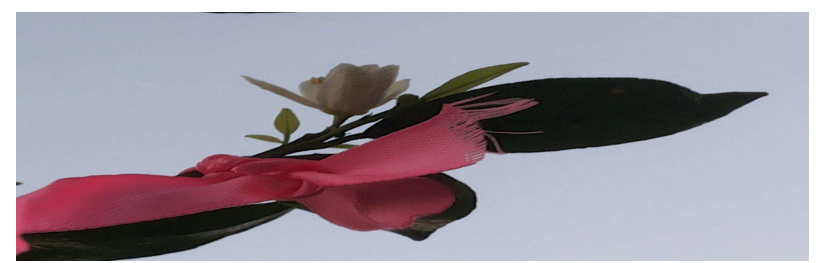

Fig.3 Starting opened flower buds citrus plants.

Citrus flower buds open it takes 2-4 days after swelling flower buds. Fragrant white flower color, which arises from young twig or the armpits of young leaves that appear in the stalk of the flower.

Phase 3 anthesis, there are two stages in the physiological processes of interest are: a. Stage when flowers start of a division (Figure 3). The parts of the flowers according Kowalska (2008) calyx (calyx) is green, canopy (crown flower / corolla), stamens / statements, pistil / pistil, flower stalks / pedicle, and receptaculum. Flower-shaped citrus compound interest in the stalk and monoecious (monoceus).

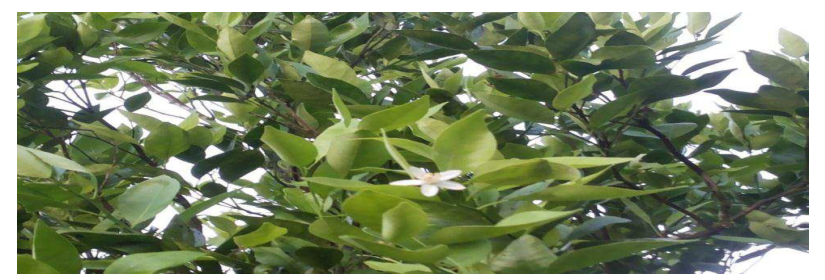

Fig. 4. Flowering citrus plants perfect

Based on observations in the field at this stage of flower development has been clearly visible flower parts in citrus plants, namely: the stigma, anthers, crown and stem extracts and flower petals. Citrus flower petals consists of 4, and 5, there is and there is not fused, with 4 and 5 petals flower base bulge jagged and notched in the stamens. White flower 
color, and smells good coming out of the armpit leaves or twigs of young shoots (Figure 4)

Phase 4 Pollination and fertilization, there are two stages,: Stage when the flowers start to fall phase leading to the development of young fruit physiologically ripe fruit, There are three stages in fruit development, namely: a). The first phase of thickening in the pericarp increased by the presence of cell division, these events typically occur for 6-8 weeks. (Figure 5)

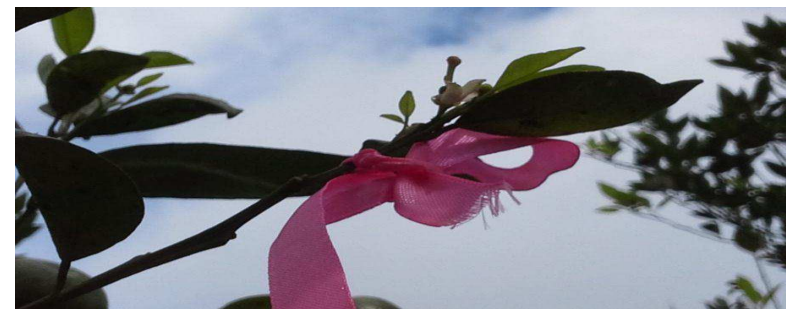

Fig. 5. The first phase of thickening in the pericarp

\section{B. MicroEnvironment Climate Experiment Locations}

Microclimate data at the location of the experiment on each flowering as in Table. Flowering in citrus plants, from the results of observations made in the field seen that the flowering citrus plants is largely determined by differences in factor micro significant factor especially rainfall, air temperature determine the formation of flowering. As with Indonesia in general Chess village had two dry season and the rainy season is influenced by the presence of wind flow across the land as well as the amount of water vapor content, realization rainfall season on-season flowering period (in January 2013) the average mm rainfall / month, while the flowering season in the off-season period (in October 2013) the average rainfall $\mathrm{mm} /$ month. Orange flower-shaped compound in one stalk, bunches or panicles. From observations in the field stemmed more two, with flower petals numbered 4-5, there were fused and there are not fused. Separate flower crown with 4-5, jagged protrusions flower base and notched in the stamens. Flowers out of the armpit leaves or shoots of young twigs, smell nice.

Based on the observation of the formation of flower buds occurs very real difference, is a result of the striking difference in agro-climate of the results observed rainfall data where there is a very large differences monthly rainfall is $543 \mathrm{~mm} /$ month and $69 \mathrm{~mm} /$ month. So also seen from the number of days of rain looks striking difference is 17.86 and the lowest was $0.19 \mathrm{~mm} /$ day which consequently lead to differences in the formation of flower buds on citrus plants. When viewed from the average air temperature occurs very noticeable difference between the on-season period with the period of-season. Microclimate data comparisons during the flowering season in the village of chess in citrus (Table1) may be used if needed for special purposes. Recommended font sizes are shown.
TABLE I

MICROCLIMATE DATA COMPARISONS DURING THE FLOWERING SEASON IN THE VILLAGE OF CHESS IN CITRUS.

\begin{tabular}{|c|c|c|c|c|c|c|}
\hline \multirow{2}{*}{$\begin{array}{c}\text { Flowerin } \\
\text { g period }\end{array}$} & \multicolumn{5}{|c|}{ Microclimate } \\
\cline { 2 - 7 } & $\begin{array}{c}\text { rainfall } \\
(\mathrm{mm} / \mathrm{mon} \\
\text { th)* }\end{array}$ & $\begin{array}{c}\text { Rainy day } \\
\text { day/month } \\
\text { /month } \\
*\end{array}$ & $\begin{array}{c}\text { The } \\
\text { maximum } \\
\text { temperature } \\
\text { ( } * *\end{array}$ & $\begin{array}{l}\text { The mi- } \\
\text { nimum } \\
\text { temperat } \\
\text { ure } \\
\text { C ** }\end{array}$ & $\begin{array}{l}\text { Average } \\
\text { temperat } \\
\text { ure } \\
\mathrm{C} * *\end{array}$ & $\begin{array}{l}\text { Air } \\
\text { humidit } \\
\mathrm{y}(\%) * *\end{array}$ \\
\hline $\begin{array}{c}\text { Period } \text { on- } \\
\text { season } \\
\text { (Juli) }\end{array}$ & 543 & 17,86 & 29,49 & 27,99 & 28,74 & 78 \\
\hline $\begin{array}{c}\text { Period } \text { off- } \\
\text { season } \\
\text { (October })\end{array}$ & 69 & 0,19 & 30,25 & 29,01 & 29,63 & 76,65 \\
\hline
\end{tabular}

Descrition : Data sources BMKG Denpasar III (2013) and average monthly of the mouth during the last 10 years (2004-2013).

\section{Establishment Number Tunas (fruit), length of shoots (cm), number of leaves (fruit), and the broad leaves of Citrus Siam}

Establishment of the number of shoots in citrus will determine the number of flowers formed, because the bud is where the growth / appearance of flower buds. From the results of the field observations it appears that the on-season period indicates the number of shoots that emerged after the observation that the highest number of leaves formed 249.08 fruit as much as 18.5 per shoots, average shoot length of 2.50 significantly different from the off-season period 20,50 on the parameters of the number of shoots, 10 sheets on the number of leaves, leaf length parameter 3.50 (Table 2).

TABLE II

FRUIT INCEPTION THE NUMBER OF SHOOTS), SHOOTLENGTH(CM), NUMBER OF LEAVES (FRUIT) AND LEAF LENGTH (CM).

\begin{tabular}{|l|c|c|c|c|}
\hline \multirow{2}{*}{$\begin{array}{l}\text { Flowerin } \\
\text { g Period }\end{array}$} & $\begin{array}{c}\text { Bud } \\
\text { Lower/ } \\
\text { plants }\end{array}$ & $\begin{array}{c}\text { he length of } \\
\text { shoots /stems } \\
(\mathrm{cm})\end{array}$ & $\begin{array}{c}\text { The number of } \\
\text { leaves (sheets) / } \\
\text { shoot }\end{array}$ & $\begin{array}{c}\text { The number of } \\
\text { leaves (sheets) / } \\
\text { shoot }\end{array}$ \\
\hline On-season & $249,08 \mathrm{a}$ & $2,50 \mathrm{a}$ & $18,50 \mathrm{a}$ & $7,90 \mathrm{a}$ \\
\hline Off-season & $20,50 \mathrm{~b}$ & $0,90 \mathrm{~b}$ & $10,00 \mathrm{~b}$ & $3,50 \mathrm{~b}$ \\
\hline BNT : $5 \%$ & 6,32 & 0,80 & 5,20 & 4,32 \\
\hline
\end{tabular}

Specification:

The figures are followed by different letters in the column

The same showed significant differences at the level of $5 \%$.

\section{Flower bud formation (fruit), Flower Blossom (fruit), Pucil Fruit (fruit)}

In this study the formation of the second observation period of flowering (flower buds and flowers bloom) can occur in both the flowering period (on-season and offseason). In observation of the formation of flower buds to bloom flower formation occurs very real difference in the period in which the on-season number of flower buds formed as 216.5 fruits and off-season period the number of flower buds are formed as much as 158 pieces as well as the variable flowers bloom formation occurred during the onseason flowers as much as 213 pieces, were significantly different in the off-season period sebanyak 78 fruit .The high flower buds at the on-season period is strongly influenced by climatic conditions were very supportive, especially the effect of temperature. This is in accordance with the opinion and Panuelas Ogaya, (2007) which says that the fruit trees flowering induction occurs naturally in the dry season, due 
to water stress and the flowers appear before the rainy season [27].

TABLE III

FLOWER BUD FORMATION (FRUIT), FLOWER BLOSSOM (FRUIT) AND FRUIT PUCIL (FRUIT)

\begin{tabular}{|c|c|c|c|}
\hline \multirow{2}{*}{$\begin{array}{l}\text { Flowering } \\
\text { Period }\end{array}$} & $\begin{array}{l}|c| \\
\text { Bud flowering } \\
\text { /plants }\end{array}$ & $\begin{array}{l}\text { Variabel } \\
\text { Flowers } \\
\text { bloom/fruit } \\
\text { plants }\end{array}$ & Fruit pucil/plant \\
\hline On-season & $216,5 \mathrm{a}$ & $213 \mathrm{a}$ & $211 \mathrm{a}$ \\
\hline $\begin{array}{c}\text { Off- } \\
\text { season }\end{array}$ & $158 \mathrm{~b}$ & $78 \mathrm{~b}$ & $68 \mathrm{~b}$ \\
\hline BNT 5\% & 6,75 & 5,54 & 5,02 \\
\hline
\end{tabular}

Specification:

The figures are followed by different letters in the column

The same showed significant differences at the level of $5 \%$.

In the pattern of flowering citrus plants (Citrus nobilis, var mikrocarpa) is influenced by environmental conditions that support. Toprik so flowering in different regions with sub-tropical regions. Average - The average number of flowers per tree blossom petals 213 and looks statistically highly significant. Low flower buds in the off-season period is supported by the low buds formed on the off-season period. Morphologically by visual observation of color changes in the leaves when shoots change from the vegetative phase to the reproductive phase. When buds entered dormancy stage, the leaves changing colors light green color becomes transparent. Color rendition leaves and flowering shoots do not flower as well as light green transparent. Sometimes though the bud enters dormancy period, the leaves turn light green transparent also did not namely produce flowers. So the citrus crop formation of transparent light green leaf color is not absolute as the identifier that the flowers will appear.

\section{CONCLUSIONS}

Based on visual observation of morphological characters change in flower development can be defined four developmental stages of flowers in citrus plants, namely: (1) shoots on induction stage or flowering shoots but has not been estimated induced, with the signs which we can observe the formation of the tops of the young leaves of light green transparent signify a few days later there will be induction of flowering. 2. flower buds appear between the armpit / tops of the plants (3) begin to form until the flower buds before the flowers bloom, here occurs maturation organs of interest, (4) Flowers bloom visually open flower jewelry. Visual observation orange flower formation is strongly influenced by rainfall factor, so as to be able to get the fruit off-season needs to be provision of water through irrigation systems. Need for further research to determine endogenously induction flowers on plants that need more indepth assessment, so from what endogenous factors that can trigger induction of flowering.

\section{REFERENCES}

[1] Berier GB, Kinet JM, Sachs RM. 1985a. The initation of flowering in The Phisiology of Flowering. Volume I. florida: CRC Press, Inc. hlm. 3-116.

[2] Chaitrakulsub S, Subhadrabandhu S Powsung T, Ogata Gemma RH. 1992. Effect of plakubutrazol on vegetative growth, flowering, fruit- set, fruit drop, fruit quality ad yield of lychee cv. Hong Huay. Acta Hort. 321:291-299.

[3] Chandrapamik, S. H. Hirapradit. U. Punnachi dan S Salakpeteh, 1992. Paclobutrazol influence flower induction in durian (Durio zebethinus Murr) Acta Hort. 321 : 282-290

[4] Daryanto, Satifah S. 1980. Pengetahuan dasar biologi bunga dan teknik penyerbukan silang buatan.Jakarta : Penerbit PT. Gramedia.

[5] Davenport, T. I. 1983. Damonozide and Gibberelin Effects on Floral Inducation of Citrus Latifolia Horticultural Science 18 : 947-949

[6] Horbath Daviid (2009). Common mechanisms regulate flowering and dormancy. United States Departement of Agricuture Research sevce Biosdence Research Lab 1505.No. 58105 United States.

[7] Dennis FG, Neilsen JC. 1999. Physiological factor affecting bienniel bearing in tree fruit : The role of seed in apple, Hort. Tecnology 9(3):317-322.

[8] Deptan (Departemen Pertanian). 2010. Data base pasar Internasional hortikultura tahun 2007-2010. Direktorat Pengolahan dan Pemasaran Hasil Hortikultura Pertanian

[9] Departemen Pertanian. 2012. Cara Budidaya ,Perkembangan Produksi Rata-rata Per Kapita Jeruk Siam di Indonesia. http://www.agribisnis.deptan. go.id.

[10] E.W Yasinta Ratna.2003.Iduksi Pembungaan Mangga Vaietas Manalagi dengan Aplikasi Paklobutrazol dan KNO3 dan Studi pembungaan.Skripsi Jurusan Biologi Fakultas Matematika dan Ilmu Pengetahuan Alam.IPB. Bogor.

[11] Fosket DE. 1994. Plant Growth and Development. A molecular approach. New York:Academic Press. Hlm. 274-341.

[12] Golsdschmidt, E. E. dan S. P Monselise, 1972.Hormonal Control of Flowering in Citrus and Some Other Woody Perennials. Dalam D.J. Carr[ed]. Plant Growth Subtancees 1970. Springer- Verlag, Berlin.

[13] Hanke, M.V., Flachowsky, A. Peil, and C. Hattasch. 2009. No Flower No Fruit-Genetic Potentials to Trigger Flowering in Fruit Tsnd Genomic 1 (1):1-20.

[14] Hempel, F..D.R. Welch, LJ. Fiedman. 2000. Floral Induction and Determination where is Flowering controlled. Trends in Plant Science 5 (1):17-21.

[15] Gene Albrigo L and JanI, Valiente, 2007. Flower Bud Induction of Sweet Orange Trees (Citrus sinensis (L) Osbeck Effect of low temperatures, Croop Load Bud age. Hrticultural science university of Florida FAS citrus Research and Education Center 700 Experiment Station Road Coke Apred FL 33850.

[16] Krajewski AJ, Rabe E. 1995. Citrus flowering: A critical evaluation. Journal of Hort. Science 70 (3):357-374.

[17] Koshita Y, Takahara T, Ogata A. 1999. Ivovement oof endogenous plant hormones (IAA,ABA,GA) in leves and flower bud formation of Satsuma Mandarin (Citrus unshiu Marc.) Scientia Horticulturae 79:185-194.

[18] Kowalska, G. 2008. Flowering Biology of Eggplant and Procedures Intensifying Fruit-set. Acta Scientiarum Polonorum, Hortorum Cultus 7(4):63-76.

[19] Lang GA. 1994. Dormancy-the missing links:Molecular studies and integration of regu;atory plant and environmental interactions. Hort. Science 29:1255-1265.

[20] Luis AG, Fomes F, Guardiola JL.1995. Leaf carbohydrate and flower formation in citrus. J Amer. Soc. Hort. Science 120 (2) : 222-227.

[21] Muhammad Thamrin, Slamet Susanto, dan Edi Santosa (2009). Effectivitas of Strangulation of Flowering Induction on Different Fruit Loads of "Cikoneng" Pummelo (Citrus grandis (L.) Osbeck). J.Agron.Indonesia37 (1) $40-45$.

[22] Ogaya, R., J. Penuelas. 2007. Drought Effects on flower and fruit Production in a Mediterranean Oak Forest. An Ynternational Journal of Fore.st Research 80(3):351-357.

[23] Pidkowich MS, Klenz JE, Haughn GW. 1999. The making of flower :controlof floralmeristemidentity in Arabidopsis. Trendsin Plant science 4(2):65-70

[24] Poerwato R. 2002. Pengaturan pembungaan mangga Gadung 21 di luar musim dengan plakobutrazol dan zat pemecah dormasi.Hayati 4 (2) :41-46.

[25] Poerwannto R, dan R. Indiastuti, 2003. Effects of Ringing on Production and Strach Fluctuation of Rambutan in off-Year Second Interna Sympo on Lycchee Longan Rambutan and Other Sapindaceae Plants. Chiang Mai.

[26] Poerwato R. 2002. Pengaturan pembungaan mangga Gadung 21 di luar musim dengan plakobutrazol dan zat pemecah dormasi.Hayati 4 (2) :41-46.

[27] Poerwanto R ., (2013). Pengembangan Jeruk UngulanIndonesia guna Pemenuhan Kebutuhan Gizi Masyarakat dan Penghematan Devisa 
Negara Tahun II. Pusat Kajian Buah Tropika (PKHT) Institut Pertanian Bogor. Bogor. Jakarta 7 Nopember 2013

[28] Porsea. 1992. Plant resources of South-East Asia Mo. 2. Edible Fruit and nuts Verheij EWM, Coronel RE (Eds). Bogor:Porsea Foundation. Hlm. 177-181.

[29] Rai I Nyoman.2004.Fisiologi Pertumbuhan dan Pembungaan Tanaman Manggis (Gracinia mangostana L.)Asal Biji dan Sambungan.(Disertasi). Bogor: Progaram Pasca Sarjana Institut Pertanian Bogor.
[30] Rai, I N., R. Poerwanro, L. K Darusman, B. S. Purwoko, 2006 Chang of Gibberellin and Stages of Mangos teen.Hayati Sep.2005 hal 101-106 ISSN, 0854-8587. Vol 13 No 3.

[31] Rai, I N., Semarajaya, C.G.A. dan Wiraatmaja, I.W. 2010. Studi Fenofisiologi Salak Gula Pasir Sebagai Upaya Mengatasi Kegagalan Fruit-set dan Memproduksi Buah di Luar Musim.J..Hort

[32] Vemmos N. 1995. Carbohidrate changes in flower, leaves, shoots and squrs of "cox's Orange sedllings, J.Hort. Sciece 53:109-113. 